Jurnal Ilmu-Ilmu Peternakan 25 (1): 16-23

ISSN: 0852-3581

E-ISSN: 9772443D76DD3

CFakultas Peternakan UB, http://jiip.ub.ac.id/

\title{
Pengaruh penggunaan ekstrak daun sirih (Piper betle linn.) pada pencelupan telur tetas itik Mojosari terhadap daya tetas dan mortalitas embrio
}

\author{
Ilham Putra Nandhra, Edhy Sudjarwo dan Adelina Ari Hamiyanti \\ Fakultas Peternakan Universitas Brawijaya \\ Jl. Veteran Malang 65145 Jawa Timur \\ ilhamnandhra@yahoo.co.id
}

\begin{abstract}
This research was carried out from October $25^{\text {th }}$ to November $22^{\text {th }} 2014$ in Tani Wanita Lestari Sejahtera group at Modopuro village, Mojosari districtMojokerto regency. The purpose of the research was to evaluate the influence of betle leaf extract in hatching eggs dyeing on the mortality and hatchability of embryos. The material of the research was 336 hatching eggs Mojosari duck owned by Mrs Suhartatik in Modopuro village. The research used experiment method by complete random scheme. The treatment consisted of four treatments and each treatment was repeated six times, so there were twenty four units of experiment. Each experiment used fourteen eggs so there were three hundred thirty six hatching eggs. The method of the treatments were $\mathrm{P} 0=$ without dyeing, $\mathrm{P} 1=$ Aquadest plus $10 \%$ of extract betle leaf, $\mathrm{P} 2=$ Aquadest plus $20 \%$ of extract betle leaf, P3= Aquadest plus $30 \%$ of extract betle leaf . The variables were hatchability and mortality of the embryos. The result of the research showed that the effect of extract betle leaf was not significant $(\mathrm{P}>0.05)$ on hatchability. Besides the effect of $30 \%$ of extract betle leaf for dyeing process was not significant $(\mathrm{P}>0.05)$ on embryos mortality. The research concluded that extract betle leaf was not able to increase hatchability and was not able to decrease duck embryos mortality. It means that extract betle leaf was not effective as substitute factor in cleaning process of hatching eggs before it was entered to the hatching machine.
\end{abstract}

Keywords: Hatchability, embryos mortality

\section{PENDAHULUAN}

Dunia perunggasan dituntut untuk menghasilkan produk yang mempunyai kualitas dan kuantitas tinggi, baik itu dari daging maupun telur, sehingga harus tersedia unggas dalam jumlah yang banyak. Jika hanya bergantung secara alami, maka jumlah unggas yang dibutuhkan tidak akan tercapai. Oleh karena itu diperlukan teknologi yang dalam waktu singkat dapat menghasilkan anakan unggas dalam jumlah yang besar. Hal ini dapat dilakukan dengan cara menetaskan telur menggunakan mesin tetas.

Aripin (2013) menyatakan kebersihan telur merupakan bagian hal terpenting dalam proses penetasan telur di dalam mesin tetas. Program desinfeksi dengan bahan kimia merupakan cara yang masih digunakan untuk mengurangi kontaminasi mikroorganisme pada telur tetas. Namun program desinfeksi ini terkadang dapat menimbulkan kema- 
tian embrio sehingga mengurangi daya tetas karena penggunaan jenis desinfektan yang kurang tepat atau dosisnya terlalu tinggi maupun pelaksanaannya yang tidak benar. Jenis desinfektan yang banyak digunakan pada proses penetasan adalah fumigasi dengan gas formaldehyde (Mahfudz, 2006). Efek utama formaldehyde yang digunakan sebagai desinfektan adalah menurunkan fertilitas telur. Selain itu penggunaan desinfektan dalam konsentrasi tinggi pada masa perkembangan embrio dapat menyebabkan abnormalitas.

Penelitian ini dilakukan untuk mencari alternatif lain pengganti desinfektan berbahan kimia dengan membuat ekstrak daun sirih yang digunakan sebagai antimikroba alami dalam proses pembersihan telur tetas. Hasil uji fitokimia ekstrak etanol daun sirih adalah bahan alami yang mengandung senyawa alkaloid, flavonoid, tanin dan minyak atsiri. Alkoloid berperan sebagai pelindung dari serangan infeksi mikroba patogen (Hoque, et al, 2011). Flavonoid dapat berperan secara langsung sebagai antibiotik dengan mengganggu fungsi dari mikroorganisme seperti bakteri atau virus. Mekanisme antibakteri tannin antara lain dapat menghambat enzim ekstraselular mikroba dan mengambil alih substrat yang dibutuhkan pada pertumbuhan mikroba, sedangkan minyak atsiri dari daun sirih mengandung $30 \%$ fenol yang dapat membunuh mikroorganisme dengan cara mendenaturasi protein sel (Nurwantoro, dkk, 2004).

\section{MATERI DAN METODE}

Penelitian ini dilaksanakan pada tanggal 25 Oktober 2014 sampai 22 November 2014 di Kelompok Tani Wanita Lestari Sejahtera Desa Modopuro Kecamatan Mojosari Kabupaten Mojokerto.

Materi yang digunakan pada penelitian ini adalah 336 butir telur tetas itik Mojosari milik Ibu Suhartatik di Desa Modopuro Kecamatan Mojosari Kabupaten Mojokerto. Telur tetas yang digunakan telah terseleksi menurut berat telur, bentuk telur, dan warna telur. Mesin tetas yang digunakan berjumlah 1 unit berukuran $150 \mathrm{~cm} \times 65 \mathrm{~cm}$ dibagi menjadi dua bagian dan masing-masing bagian berkapasitas 165-170 butir sehingga 1 unit mesin tetas dapat menampung 340 butir.

Metode yang digunakan dalam penelitian ini adalah metode percobaan dengan menggunakan Rancangan Acak Lengkap (RAL). Perlakuan yang dilakukan sebanyak 4 dan masing-masing perlakuan diulang 6 kali, sehingga terdapat 24 unit percobaan. Setiap 1 unit percobaan terdiri dari 14 butir sehingga jumlah telur tetas yang digunakan adalah 336 butir. Perlakuan yang diberikan adalah:

$\mathrm{P}_{0}($ Konsentrasi $0 \%)=$ Tanpa pencelu pan

$\mathrm{P}_{1}$ (Konsentrasi 10\%) $=10 \mathrm{ml}$ ekstrak daun sirih $+100 \mathrm{ml}$ aquadest

$\mathrm{P}_{2}$ (Konsentrasi 20\%) $=20 \mathrm{ml}$ ekstrak daun sirih $+100 \mathrm{ml}$ aquadest

$\mathrm{P}_{3}$ (Konsentrasi 30\%) $=30 \mathrm{ml}$ ekstrak daun sirih $+100 \mathrm{ml}$ aquadest

Variabel yang diteliti dalam penelitian ini adalah daya tetas dan mortalitas embrio. Data daya tetas dan kematian embrio yang diperoleh diuji secara statistik. Bila hasil sidik ragam menunjukkan perbedaan nyata, dilanjutkan dengan uji jarak berganda Duncan (UJBD) untuk mengetahui perbedaan antar perlakuan.

\section{HASIL DAN PEMBAHASAN}

\section{Pengaruh pencelupan telur tetas menggunakan ekstrak daun sirih terhadap daya tetas}

Daya tetas diartikan sebagai persentase telur yang menetas dari telur yang fertil. Ningtyas, dkk (2013) menambah- 
kan daya tetas telur adalah banyaknya telur yang menetas dibandingkan dengan banyaknya telur fertil dan dinyata- kan dalam persen. Hasil perhitungan daya tetas dapat dilihat pada Tabel 1 .

Tabel 1. Data pengaruh pencelupan telur tetas menggunakan ekstrak daun sirih terhadap daya tetas

\begin{tabular}{cc}
\hline Perlakuan & Rataan daya tetas $(\%)$ \\
\hline P0 & $33,33 \pm 15,43$ \\
P1 & $46,43 \pm 16,13$ \\
P2 & $39,29 \pm 17,35$ \\
P3 & $29,76 \pm 9,49$ \\
\hline
\end{tabular}

Tabel 1 menunjukkan bahwa pengaruh pemberian ekstrak daun sirih memberikan perbedaan pengaruh yang tidak nyata terhadap daya tetas. Hal ini didukung oleh hasil analisis ragam bahwa dengan adanya pencelupan telur tetas menggunakan ekstrak daun sirih sampai dengan 30\% memberikan pengaruh yang tidak nyata $(\mathrm{P}>0,05)$ terhadap daya tetas. Pemakaian ekstrak daun sirih sampai dengan 30\% memang benar bisa menghambat pertumbuhan koloni bakteri dengan tidak ditemukannya mikroorganisme seperti lalat ataupun serangga pada telur. Hal ini telah diungkapkan oleh Sari, dkk (2008) bahwa ekstrak daun sirih yang dipakai sebagai antiseptik pada kadar ekstrak 15\% menghasilkan jumlah pertumbuhan koloni bakteri berkurang sampai dengan $50 \%$.

Aripin (2013) mengungkapkan penggunaan infusa daun sirih sebagai bahan sanitasi pencelupan telur itik dengan konsentrasi $30 \%$ daya tetas optimal dicapai sebesar $82,50 \%$ dan kematian embrio $17,50 \%$, sedangkan dari perlakuan tanpa penggunaan infusa daun sirih diperoleh rataan daya tetas sebesar
$70,22 \%$. Oleh karena itu ekstrak daun sirih dapat dijadikan sebagai antimikroba, namun penggunaan ekstrak daun sirih sampai dengan $30 \%$ ini belum bisa efektif untuk meningkatkan daya tetas. Hal ini bisa terjadi karena terlalu pekatnya ekstrak sehingga menutupi kerabang telur yang menyebabkan sulitnya itik keluar saat proses menetas (Fujiawati, dkk, 2012).

Sirait (1986) menjelaskan telur itik memiliki kerabang yang tebal dan jumlah pori-porinya sedikit. Pori-pori yang terdapat pada tiap butir telur berkisar antara $7.000-17.000$ dan menyebar di seluruh permukaan telur. Kulit telur pada bagian tumpul memiliki jumlah pori-pori per satuan luas lebih banyak dibandingkan dengan pori-pori bagian yang lain. Hal ini memperparah kondisi telur yang diberi perlakuan sebanyak 30\% karena kerabang telur yang sudah tebal akan menjadi semakin tebal dan menyebabkan itik kesulitan memecahkan cangkang telur, sehingga bisa menyebabkan kematian. Persentase daya tetas pada konsentrasi $0 \%, 10 \%, 20 \%$ dan 30\% dapat dilihat pada Gambar 1. 


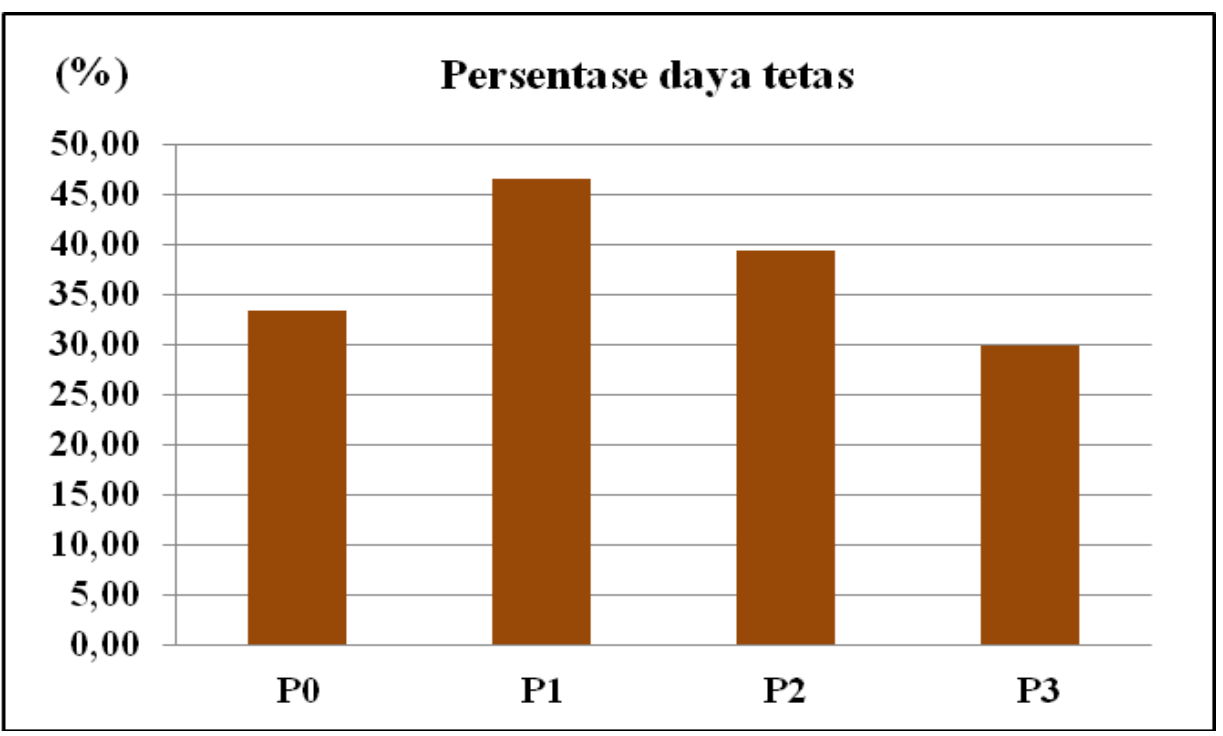

Gambar 1. Diagram pengaruh pemberian ekstrak daun sirih pada pencelupan telur tetas itik terhadap daya tetas dari masing-masing perlakuan

Walaupun secara statistik tidak memberikan perbedaan pengaruh yang nyata, namun penggunaan ekstrak daun sirih dengan konsentrasi $10 \%$ memiliki daya tetas lebih tinggi daripada perlakuan kontrol. Hal ini terjadi karena pada perlakuan konsentrasi $10 \%$ merupakan takaran yang paling tepat sehingga dihasilkan larutan yang tidak terlalu pekat, sedangkan pada perlakuan konsentrasi 30\% menghasilkan larutan yang paling pekat sehingga dapat menurunkan daya tetas. Ghofir, dkk (2014) menjelaskan bahwa konsentrasi $10 \%$ bisa efektif mencegah tumbuhnya bakteri pada telur salah satunya Salmonella typhimurium. Selain itu, didalam ekstrak daun sirih mengandung minyak atsiri yang bersifat menghambat pertumbuhan mikroba dan jamur. Komposisi dalam minyak atsiri terdiri dari senyawa fenol, turunan fenol propenil (sampai 60\%) serta zat anti mikroorganisme dan zat penyamak (Parubak, 2013), zat anti mikroorganisme berupa polyfenol yaitu kavibetol dan kavikol (Susanti, 2008).

Hajare, et al (2009) menjelaskan kavikol berperan sebagai pemberi bau khas pada daun sirih dan memiliki daya bunuh bakteri lima kali lipat lebih tinggi daripada fenol biasa khususnya pada salah satu bakteri yang terdapat pada telur tetas itik yaitu Staphylococcus aureus. Kavibetol merupakan fenol yang khas dari minyak atsiri dan biasa disebut dengan betlefenol. Selain itu kavibetol juga berkhasiat mensucikan kuman sehingga pada konsentrasi $10 \%$ bisa didapatkan daya tetas yang lebih tinggi dari perlakuan kontrol. Cara kerja polyfenol dalam membunuh mikroorganisme yaitu dengan cara mendenaturasi protein sel, sehingga semua aktivitas metabolisme sel dikatalisis oleh enzim yang merupakan suatu protein, sehingga sifat kulit telur dapat berubah ke arah impermeabel atau tidak bisa ditembus air dan gas. Hal ini dapat menghambat keluarnya air dan gas-gas dalam telur. Ekstrak daun sirih juga mengandung senyawa fitokimia berupa tannin.

Tannin terutama dimanfaatkan untuk proses penyamakan kulit. Tannin merupakan polifenol yang larut dalam air. Mekanisme antibakteri tannin antara lain menghambat enzim ektraseluler mikroba, mengambil alih substrat yang dibutuhkan pada pertumbuhan mikroba, atau bekerja langsung pada metabolisme dengan cara menghambat proses oksida- 
si, sehingga keluarnya air dan gas-gas dalam telur dapat dicegah (Nurwantoro dkk, 2004). Hermiati, dkk (2013) menambahkan bahwa didalam ekstrak daun sirih juga terdapat senyawa flavonoid dan polivenol yang berfungsi sebagai antioksidan, antideabetik, antikanker, antiseptik dan antiflamasi, dan dalam beberapa kasus flavonoid dapat berperan secara langsung sebagai antibiotik dengan mengganggu fungsi dari mikroorganisme seperti bakteri atau virus. Selain itu ada juga senyawa alkaloid yang dihasilkan oleh tumbuhan sebagai bagian dari sistem pertahanan diri. Senyawa terse- but berperan sebagai pelindung dari serangan infeksi mikroba patogen.

\section{Pengaruh pencelupan telur tetas menggunakan ekstrak daun sirih terhadap mortalitas embrio}

Mortalitas embrio atau kematian embrio merupakan kematian yang terjadi pada embrio saat didalam cangkang atau saat belum menetas. Kematian embrio didalam telur umumnya terjadi dalam periode awal penetasan dan periode akhir penetasan (Ningtyas, dkk, 2013). Hasil perhitungan mortalitas embrio dapat dilihat pada Tabel 2 .

Tabel 2. Data pengaruh pencelupan telur tetas menggunakan ekstrak daun sirih terhadap mortalitas embrio

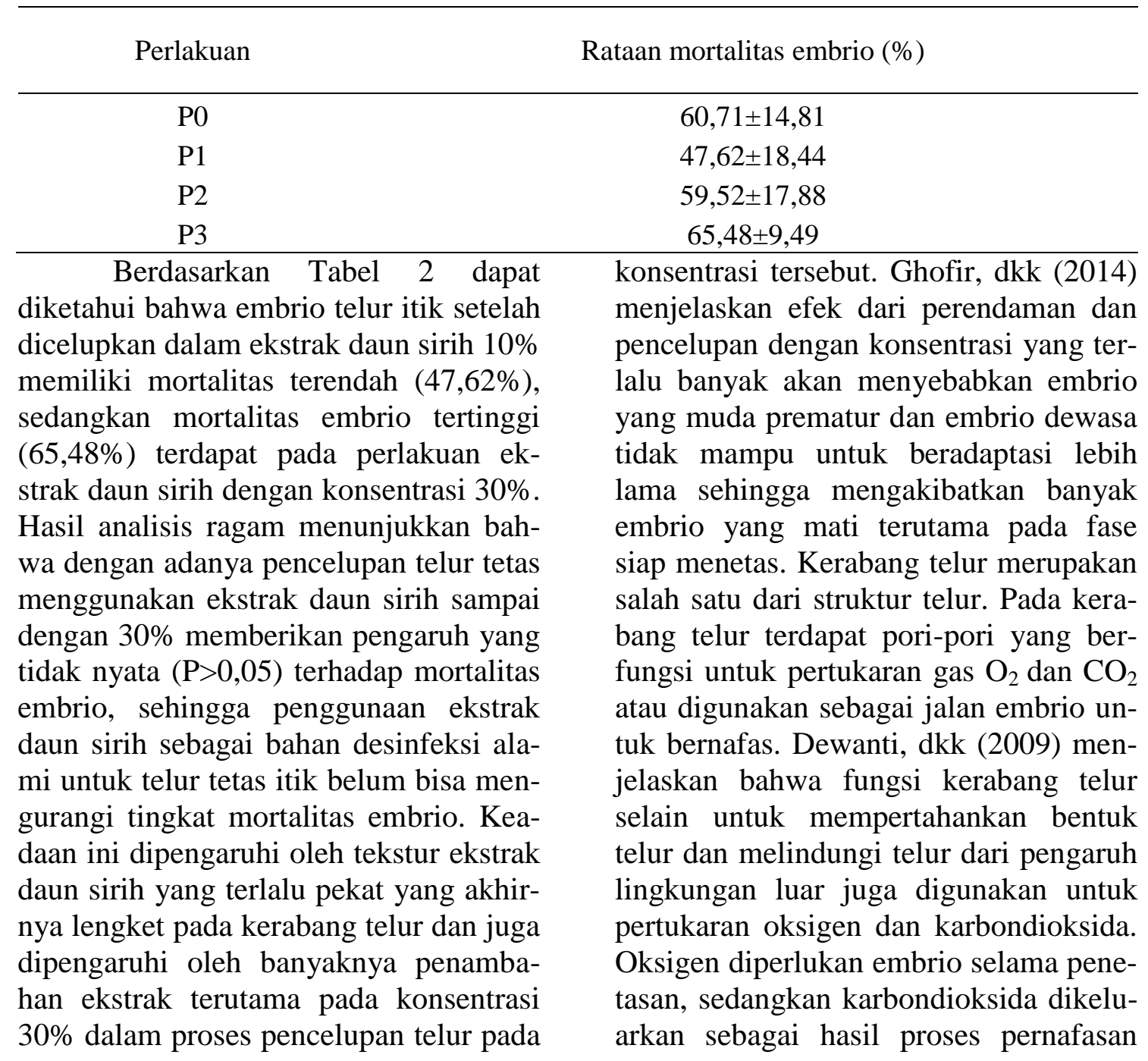


embrio. Apabila ekstrak daun sirih yang digunakan sebagai bahan desinfeksi telur tetas memiliki konsentrasi 30\%, maka akan mengakibatkan tingkat mortalitas embrio menjadi lebih tinggi, terutama pada saat umur telur memasuki hari ke21 sampai hari ke-26 atau pada 7 hari sampai 2 hari menjelang telur menetas, karena hari-hari tersebut merupakan masa-masa kritis untuk embrio. Persentase mortalitas embrio pada konsentrasi $0 \%$, $10 \%, 20 \%$ dan $30 \%$ dapat dilihat pada Gambar 2.

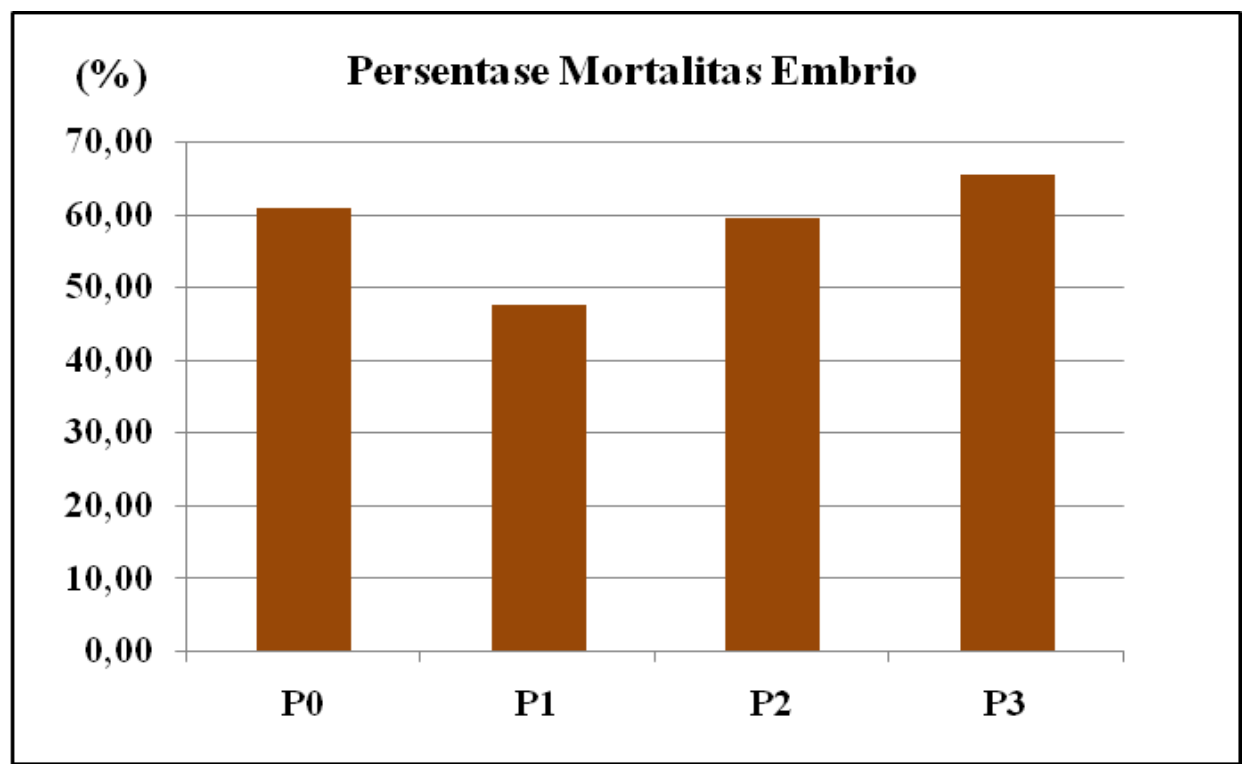

Gambar 2. Diagram pengaruh pemberian ekstrak daun sirih pada pencelupan telur tetas itik terhadap mortalitas embrio dari masing-masing perlakuan

Bachari, dkk (2006) menjelaskan bahwa tingkat kematian embrio yang banyak terdapat pada masa kritis yaitu pada tiga hari pertama penetasan dan tiga hari sebelum jangka waktu menetas. Selama proses penetasan perkembangan embrio tidak hanya dipengaruhi oleh bahan desinfeksi saja namun dapat juga dipengaruhi oleh proses penanganan saat penetasan (Wicaksono, dkk, 2013). Penanganan telur tetas dilakukan untuk menghindari terjadinya kerusakan (fisik/kimia dari telur) yang bisa menurunkan daya tetas dan meningkatkan mortalitas. Penanganan telur yang baik sangat penting karena didalam telur sudah terdapat embrio yang sedang berkembang. Kerusakan fisik dapat disebabkan karena benturan, proses pengemasan yang salah, transportasi dan kerabang yang tipis. Sedangkan kerusakan/perubahan komposisi telur dapat disebabkan karena suhu, kelembaban dan penyimpanan yang lama (Nurhalimah, dkk, 2014).

Penanganan eksplode atau meletusnya telur ternyata juga harus diperhatikan saat proses penetasan berlangsung. Kejadian eksplode ini sering terjadi pada hari terakhir penetasan karena embrio yang telah mati tidak segera diketahui sehingga terjadi pembusukan. Pembusukan ini terjadi karena tingginya kelembaban setelah dilakukannya pembasahan telur yang menyebabkan adanya pertumbuhan bakteri. Bakteri pada embrio yang mati mengeluarkan $\mathrm{CO}_{2}, \mathrm{NH}_{3}$, dan $\mathrm{H}_{2} \mathrm{~S}$ yang akan menyebabkan telur meletus (Widyaningrum, dkk, 2014).

Kejadian eksplode didalam mesin tetas ini akan menimbulkan percikan yang dapat menempel ke telur lain sehingga embrio yang terdapat didalam 
telur tersebut akan mati. Hal ini didukung oleh Fitri (2007) yang menyebutkan bahwa telur merupakan media pertumbuhan yang baik bagi mikroorganisme, karena telur mengandung senyawa-senyawa yang dapat menjadi sumber nutrisi yang dibutuhkan oleh mikroorganisme, sehingga dapat menyebabkan kerusakan pada telur.

\section{KESIMPULAN}

Berdasarkan dari hasil penelitian bahwa penggunaan ekstrak daun sirih sebagai bahan alami pada proses pencelupan telur tetas itik Mojosari pada konsentrasi $10 \%$ memberikan rata-rata persentase daya tetas tertinggi yaitu $(46,43 \%)$ dan mortalitas terendah $(47,62 \%)$.

\section{DAFTAR PUSTAKA}

Aripin. 2013. Pengaruh konsentrasi in fusa daun sirih (Piper betle Linn.) pada pencelupan telur itik terhadap daya tetas dan kematian embrio. J. In don. Trop. Anim. Agric. 26 (4).

Bachari, I., Sembiring, I. dan Tarigan, S. 2006. Pengaruh frekuensi pemutaran telur terhadap daya tetas dan bobot badan DOC ayam kampung. Jurnal Agribisnis Peternakan 2 (3): 101-105.

Dewanti, R., Yuhan, dan Sudiyono. 2009. Pengaruh bobot dan frekuensi pemutaran telur terhadap fertilitas, daya tetas, dan bobot tetas itik lokal. Buletin

Peternakan 38 (1): 16-20. ISSN 0126-4400

Fujiawati, W. D., Sujana, E. Darana, S. 2012. Pengaruh konsentrasi asap cair tempurung kelapa pada fumigasi telur itik terhadap daya tetas dan kematian embrio. Seminar Nasional Teknologi Peternakan dan Veteriner. Fakultas Pe- ternakan Universitas Padjadjaran Jatinangor.

Fitri. A. 2007. Pengaruh penambahan daun salam (Eugenia polyantha Wight) terhadap kualitas mikrobiologis, kualitas organoleptis dan daya simpan telur asin pada suhu kamar. Jurnal Pangan dan Agroindustri 2 (5): 6-28.

Ghofir, M., Sugihartono, M., Thomas, R. 2014. Efektivitas pemberian ekstrak daun sirih (Piper betle. L.) terhadap penetasan telur ikan gurami (Osphronemus gouramy. Lac). Jurnal Ilmiah Universitas Batanghari Jambi 14 (1): 37-44.

Hajare, R., Darvheker, V. M., Shewale, A. and Patil, V. 2009. Evaluation of antihistaminic activity of $P i$ per betle Leaf in Guinea Pig. African Journal of Pharmacology 5 (2): 113-117.

Hermiati, Rusli., Manalu, N. Y., Sinaga, M. S. 2013. Ekstrak daun sirih hijau dan merah sebagai antioksidan pada minyak kelapa. Jurnal Teknik Kimia USU. 2 (1): 2-7.

Hoque, M. M., Rattila, S., Shishir, A. M., Bari, M. L., Inatsu, Y. and Kawamoto, S. 2011. Antibacterial activity of ethanol extract of Betle Leaf (Piper betle L.) against some food borne pathogens. Bangladesh J Microbial 26 (2): 58-63.

Mahfudz, L. D. 2006. Hidrogen peroksida sebagai desinfektan pengganti gas formaldehyde pada penetasan telur ayam. Jurnal Protein 13 (2): 6-12.

Ningtyas, M. S., Ismoyati, I. H., dan Sulistyawan. 2013. Pengaruh temperatur terhadap daya tetas dan hasil tetas telur itik (Anas plathyrinchos). Jurnal Ilmiah Peternakan 1 (1) : 347-352. 
Nurhalimah, H., Wijayanti, N. Widyaningsih, T. D. 2014. Efek antidiare ekstrak daun beluntas (Pluchea Indica L.) terhadap mencit jantan yang diinduksi bakteri Salmonella Thypimurium. Jurnal Pangan dan Agroindustri 3 (3): 1083-1094.

Nurwantoro, Y. B., dan Resmisari. 2004. Pengaruh perendaman jus daun sirih (Piper betle L.) terhadap jumlah bakteri pada telur itik. Journal Indonesia Tropic Animal Agriculture. 3 (1): 156160.

Parubak. A. S. 2013. Senyawa flavonoid yang bersifat antibakteri dari akway (Drimys Becariana. Gibbs). Chem. Prog. 6 (1).

Sari, I., dan Iadiartuti, D. 2008. Studi efektivitas sediaan gel antiseptik tangan. Jurnal UGM, Yogyakarta.

Sirait. C. H. 1986. Telur dan pengolahannya. Pusat Penelitian dan
Pengembangan Peternakan, Bogor.

Susanti. A. 2008. Daya antibakteri sari etanol daun sirih (Piper betle L.). terhadap Escherichia coli secara in vitro. Fakultas Kedokteran Hewan Universitas Airlangga. http://journal.unair.ac.id. Diakses pada tanggal 4 Januari 2015.

Wicaksono, D., T. Kurtini, K. Nova. 2013. Perbandingan fertilitas serta susut, daya dan bobot tetas ayam kampung pada penetasan kombinasi. Seminar Nasional Teknologi Peternakan dan Veteriner. Fakultas Pertanian, Universitas Lampung.

Widyaningrum, A., Sudjarwo, E dan Achmanu, Z. 2012. Pengaruh jenis bahan dan frekuensi penyemprotan terhadap daya tetas, bobot tetas, dan dead embryo telur itik khaki Campbell. Journal Indonesia Tropic Animal Agriculture. 6 (2): 2-13. 